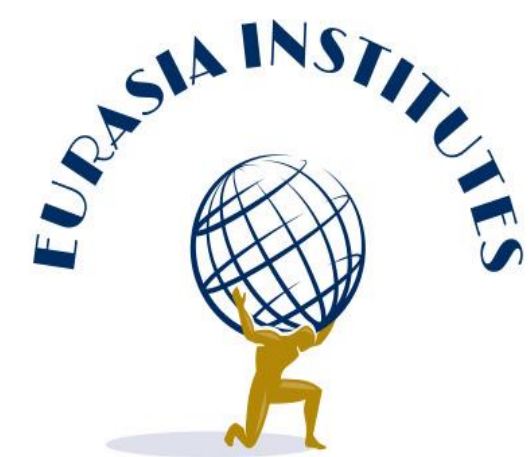

DOI: $10.47669 / P S P R P-1-2020$

\title{
Overcoming the Authoritarian Legacy? Understanding Regime Change in Ukraine
}

Aram Terzyan

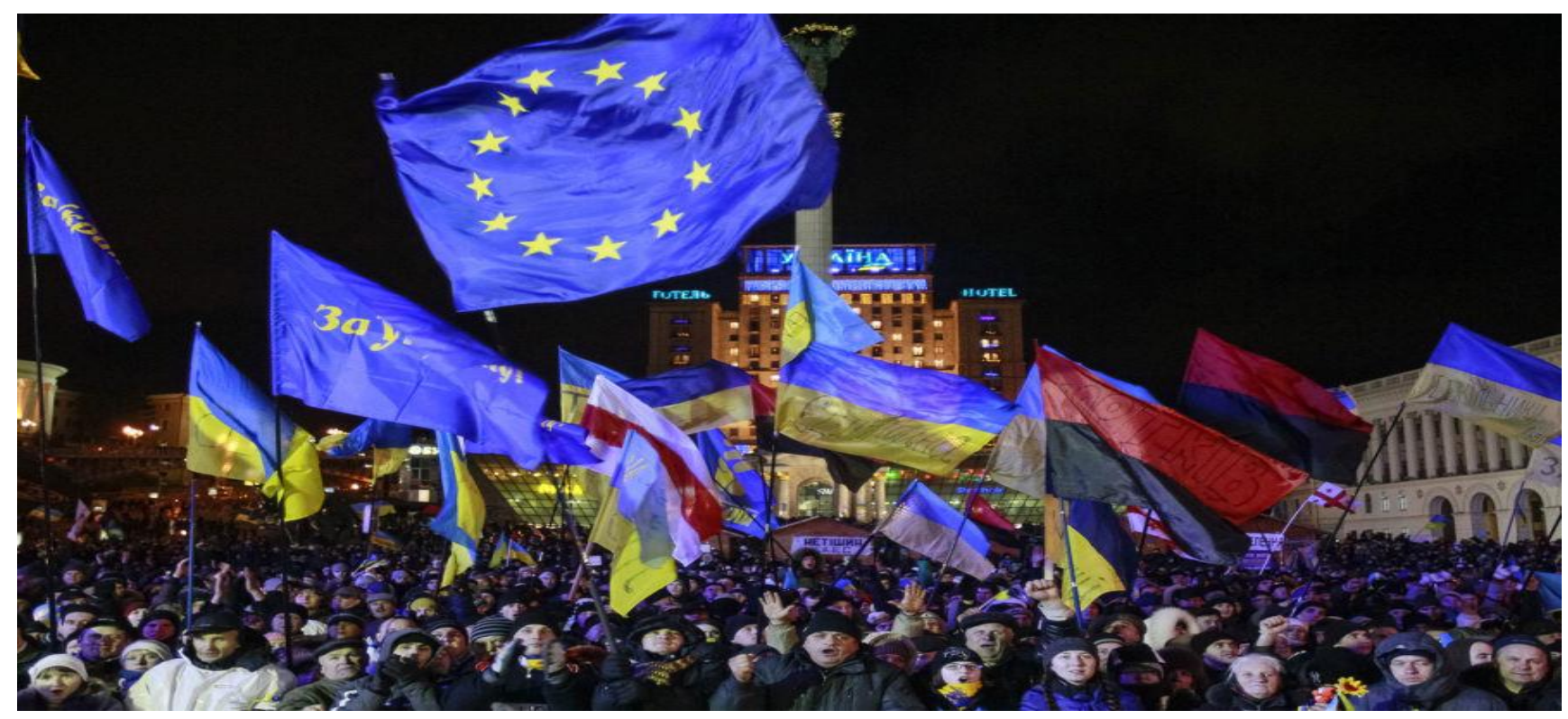

Center for East European and Russian Studies 


\begin{abstract}
The 2014 Maidan Revolution in Ukraine is largely deemed to herald the end of the post-Cold War settlement, by reasserting Ukraine's determination in overstepping the "buffer zone" and gaining centrality in the European Union (EU) -led socio-political order. A question remains as to what extent the "choice for Europe" has shaped Ukraine's regime outputs, thus leading to country's transformation into a full-fledged democracy. The answer to this question involves explaining the post-Maidan dynamics of democratic consolidation, with a focus on its attitudinal, behavioral, and institutional dimensions. The study concludes that while broad democratic support is conducive to democratic consolidation, the latter involves overcoming the deep-rooted informality and 'culture of corruption'. Besides, reinforcing the institutional foundations of democratization is critical to ensuring its sustainability.
\end{abstract}

Keywords: Ukraine, Maidan Revolution, regime change, democracy consolidation.

\title{
Introduction
}

This paper explores the dynamics of regime change, as well as the challenges of democracy consolidation in Ukraine after the 2014 Maidan Revolution.

EuroMaidan - the word, which began as a Twitter hashtag, is widely regarded as the last 'antiSoviet' revolution - defying the post-Soviet order and forging a new Ukrainian nation (Gerasimov, 2014; Stepanenko, 2015).

A great many observers have put the Ukrainian revolution in the framework of intensifying geopolitical confrontation between the West and Russia, and even contend that Maidan put post-Cold War system of international relations to a serious test (Fedunyak, 2015, p. 103). By confirming its European choice, Ukraine made a huge stride in overstepping the post-Cold War "buffer zone" and redefining its place within Europe. A question remains as to what extent the "choice for Europe" has shaped Ukraine's regime outputs, thus leading to country's transformation into a full-fledged democracy.

Despite the fact, that Ukraine's post-Maidan state - building has recently become a subject of analysis, there has been little attention to the various aspects of country's democratic consolidation. This article contributes to the debates through exploring the attitudinal, behavioral, and institutional dimensions of democratic consolidation. Based on these observations, this article seeks to address the following research questions: 1. How does the literature conceptualize the Maidan Revolution? 2. What are the core behavioral, attitudinal, and institutional challenges to Ukraine's democratic consolidation.

The paper does not pretend to be able to evaluate the effectiveness of the Ukrainian leadership in achieving the general goals of democracy, prosperity, and security. Instead, it focuses on the main factors that drive or hinder democratic reforms, leading to democratic consolidation 
Overcoming the Authoritarian Legacy? Understanding Regime Change in Ukraine

This paper is an in-depth case analysis, that uses policy analysis and process tracing to examine the core dynamics of post-revolution transformation and democratic consolidation in Ukraine.

\section{Understanding the Revolution of Dignity}

According to widely held beliefs, the protest phenomenon and subsequent people's revolt, known as the EuroMaidan - the word, which began as a Twitter hashtag, is the most radical attempt at de- institutionalizing post-Soviet politics and order since 1991 (Stepanenko, 2015, p. 30). Zhuk and Gerasimov treat the Ukrainian Maidan as the last anti-Soviet (Zhuk, 2014, p. 195) or even first "postcolonial revolution," as "it is all about the people acquiring their own voice, and ... forging a new Ukrainian nation." (Gerasimov, 2014, p. 22). Similarly, some observers claim that "a new Ukraine was born on the Maidan," by means of protests that not only changed the political landscape of the country, but also people and their outlook (Diuk, 2014, p. 84).

A great many observers have put the Ukrainian revolution in the framework of intensifying geopolitical confrontation between the West and Russia, and even contend that Maidan put post-Cold War system of international relations to a serious test (Fedunyak, 2015, p. 103). This is where the "clash of civilizations" narrative comes in, with a tendency to frame the conflict with Russia as an "ideological confrontation" and even a demonstration of an antagonism between democracy and autocracy (d'Anieri, 2015; Delcour and Wolczuk, 2015). Diuk analyzes the harrowing challenges facing the post-Cold War order in Europe, and posits that the chances of democratization across a vast swath of Eurasia seem slimmer now, than ever before in the face of Russian President Vladimir Putin's crackdown on liberal-democratic forces at home and abroad (Diuk, 2014, p. 83). Such claims are not novel. Conventional logic posits that the Kremlin has a strong interest in ensuring that regional and global democratic trends do not affect grip on the Russian political system and that the legitimacy of democracy promotion and regime change are subverted (Roberts and Ziemer, 2018). This line of thinking presumes that Russia poses threats to liberal democracies by rolling back democracy around the world and bringing down democratic governments in its neighborhood and beyond (Ambrosio, 2007). Shevtsova notes that the pro-EU, democratic movement in Ukraine heightened Putin regime's fears about its possible spillover into Russia, amid lingering concerns about recurrence of large-scale post-election protests that erupted in 2011. In response, Putin resorted to reinforcing personalistic leadership, sparing no effort to undermine Western influence over its "near neighborhood" (Shevtsova, 2014, p. 74). Thus, Shevtsova concludes that the crisis in Ukraine stems from Russia's struggle to control Ukraine and keep it in the orbit of its authoritarian influence, as opposed to the Ukrainians' "choice for Europe" (p. 74). Such an antagonism comes down to the evolution of the 
Kremlin's foreign policy thinking during Vladimir Putin's presidency, that led to the establishment of an opposing ideology to the Western/European one based on Russian ethnic nationalism, conservative values and the Russian Orthodox church. This new ideology and the increasingly antiwestern rhetoric contributes significantly to substantial othering of Russia and its portrayal as Europe's "Other" in European political thinking (Neumann, 2016). As a result, Russia is increasingly defining itself as a rival to the EU with the creation of the Eurasian Union and thus strives construct a Eurasian identity (Stefánsson, 2015). In this regard the Maidan Revolution can be viewed as a manifestation of "clash of civilizations" between European and Eurasian projects that confirmed Ukraine's "choice for Europe." It came as a response to Ukrainian President Viktor Yanukovich's abrupt policy shift from pro-European to pro-Russian, that prompted thousands of demonstrators to take the streets and stand up for their European choice (Shveda and Ho Park, 2016, p. 85).

Overall, the Ukrainian revolution is deemed to herald the end of the post-Cold war settlement that vanished the hopes of Euro-Russian integration (Shevtsova, 2014, p. 74). That said, instead of joining the Western civilization, Russia positioned itself as its "Other" and resorted to what Delcour and Wolczuk refer to as alternative region building or region-spoiling measures aimed at securing its regional hegemony (Delcour and Wolczuk, 2017). As a result, Ukraine found itself in the midst of confrontation between "a constrained EU" and "assertive Russia" (Kuzio, 2017, p. 103) as a "bone of contention between them" (Samokhvalov, 2015, p. 1371).

By contrast some Russian analysts tend to regard the Maidan as a "Western conspiracy" (Krilova, 2015; Markov, 2017) This line of thinking tends to claim that Cold War thinking never went away from Western perceptions of international relations, and even sees that as part of the crisis outbreak in Ukraine (Black and Johns, 2016). Some analysts claim that the main cause of the crisis was post-Soviet "Western triumphalism" that resulted in the rapid and unstoppable growth of NATO and the EU (xvii). Igor Ivanov, Putin's first foreign minister, even suggested that the crisis in Ukraine is more dangerous than the Cold War, "during which international relations were confined at least to a 'certain order' by the United Nations and international law and kept that way by a mutual fear of nuclear holocaust” (p. 227). Meanwhile, nowadays, the norms of international relations are outweighed by political interests on all sides, and the risk of uncontrolled escalation is even greater, as there still is no mutually acceptable mechanism to prevent military clashes (p. 227).

In contrast to geopolitical interpretations, some observers specifically focus on the socioeconomic factors behind the revolution. Examining the social media framing of the Ukrainian Euromaidan protest movement Surzhko-Harned and Zahuranec suggest that unlike foreign media sources' portrayal of the Ukrainian crisis as a geopolitical struggle, participants of the protest would conceptualize their movement in terms of domestic issues and an anti-system revolt rather than a 
Overcoming the Authoritarian Legacy? Understanding Regime Change in Ukraine

geopolitical confrontation between Russia and the EU (Surzhko-Harned and Zahuranec, 2017, p. 758).

Shveda focuses on social and economic discontent of the Ukrainian society as a driving force behind the revolution. This came as no surprise, given that among 26 European nations, Ukrainians appeared to be most dissatisfied with their life (4.82 points on a 10-point scale), with tremendous discontent with government activities (2.25 points) and the state of economy (2.25 points) (Shveda, 2015, p. 92). A closer look at the majority of Facebook comments, shows that many Ukrainians viewed deferral of the Association Agreement with the European Union as a "stab in the back" that put an end to much-awaited reforms. Thus, Mustafa's call to action swiftly resonated with outraged and disillusioned Ukrainians (Bohdanova, 2014, p. 135).

Some observers give great weight to the mobilizing power social media in Ukraine's Euromaidan uprising (Piechota and Rajczyk, 2015). Clearly, it is increasingly challenging to maintain autocratic rule in a country, where youth-driven, social media-powered society refuses to abide by "post-Soviet rules" and craves for democracy. Bohdanova relies on the mobilizational power of social media to explain how a large-scale popular uprising, like Maidan, came to fruition in the absence of strong political opposition or a coalition of political and civic organizations behind it (Bohdanova, 2015, p. 133). She singles out Twitter as a powerful tool for helping protesters identify and connect with one another, as well as for shedding light on ongoing events for the wider audience and international community. As a result of effective online consolidation, Twitter accounts@euromaidan, @EuroMaydan, and @EuroMaydan_eng_-that rapidly appealed to tens of thousands of followers (p. 136).

In sum, the analyses of the Maidan Revolution range from its treatment as a manifestation of the intensifying geopolitical confrontation between the West and Russia, to its reductionism to economic discontent, fueled by the mobilizational power of the social media. Yet, there seems to be a broad consensus on Maidan being a testament to the crisis of the post-Soviet political model resting on repressive rule, as well as a manifestation of the growing antagonism between the European and Russian visions of the shared neighborhood.

\section{The challenges of democratic consolidation}

One of the intriguing questions revolving around post-revolution state-building in Ukraine is whether and to what extent the domestic change will lead to eradicate its deep-rooted authoritarian practices, thus paving the way for democracy consolidation.

The 2014 Revolution of Dignity has sparked optimistic commentaries about country's gradual transition from competitive authoritarianism to a consolidated democracy. 
Indeed, to succeed on the path to democracy consolidation, the country needs to overcome the authoritarian legacy of the past and undergo fundamental reforms.

Originally, the term "democratic consolidation" was narrowed down to describing the issues of making newborn democracies stable and immune to the threat of authoritarian "reverse waves" (Schedler, 1998).

Linz and Stepan (1996) offer a middle-of-the-road definition of a consolidated democracy: Constitutionally, a democratic regime is consolidated when governmental and nongovernmental forces alike throughout the territory of the state become subject to, and habituated to, the resolution of conflict within the bounds of specific laws, procedures, and institutions sanctioned by the new democratic process (Linz and Stepan, 1996, p. 6). Behaviorally a democratic regime in a territory is consolidated when no significant national, social, economic, political, or institutional actors spend significant resources attempting to achieve their objectives by creating a nondemocratic regime or turning to violence or foreign intervention to secede from the state (p. 6). Attitudinally, a democratic regime is consolidated when a strong majority of public opinion, holds the belief that democratic procedures and institutions are the most appropriate way to govern collective life in a society such as theirs, and when support for anti-system alternatives is quite small or more-or-less isolated from prodemocratic forces (p. 6).

Given that mass level attitudes towards democracy are viewed as the building blocks of democratic stability and fundamental elements of a functional democracy, much of the literature on democratic consolidation has centered around the establishment and promotion of democratic values and attitudes (Gunther and Montero, 2006, p. 46; Linz and Stepan, 1996, p. 6).

Gunther and Montero (2006) stress the necessity of clearly separating such attitudes into three different clusters, which they call democratic support, political discontent, and political disaffection (Gunther and Montero, 2006, p. 46). These three sets of attitudes have quite different behavioral correlates or consequences: a lack of fundamental support for democracy is strongly associated with votes for anti-system parties; political discontent is clearly linked with votes against the incumbent party or governing coalition; and political disaffection is part of a broader syndrome of alienation and disengagement from active involvement in the political (p. 46).

Schedler (1998) notes that over time the "mission" of democratic consolidation has expanded, incorporating crucial tasks, such as party building, neutralization of anti-system actors, decentralization of state power, promotion of civil society organizations, judicial reforms, as well as alleviation of poverty and economic development (Schedler, 1998).

One of the key elements of democratic consolidation is institutionalization, aimed at translating individuals' visions into policies sustained by appropriate structures, rules, and procedures. 
Overcoming the Authoritarian Legacy? Understanding Regime Change in Ukraine

This comes down to "transforming the accidental arrangements, prudential norms and contingent solutions . . . into relationships that are reliably known, regularly practiced and normatively accepted" (Usul, 2010, p. 4). Clearly, it is in this context that the advancement of a vibrant civil society and competitive party politics with well-institutionalized political parties and civil society organizations acquire critical relevance.

Building on the literature on democratic consolidation, this study specifically explores behavioral, attitudinal aspects of democracy consolidation in post-Maidan Ukraine, focusing on the issues of institutionalization and civil society consolidation.

\section{Attitudinal and behavioral dimensions of democratic consolidation}

Relevant attitudes towards democracy are of several different kinds and have differing but significant impacts on democratic performance. In terms of democratic support, which is indeed critical to democratic consolidation, it is noteworthy, that positive attitudes towards democracy and integration with the West have remained robust in Ukraine even amid economic downturn facing the country from 2013 to 2015. Namely, the escalating crisis in Ukraine inflicted immense economic suffering on the Ukrainian population, fraught with rising unemployment that rose from over 8.5 to 11 percent (Alexseev, 2019), as well as a sharp decline (12 percent) in GDP (Ibtimes, 2015). Despite the economic slowdown and ensuing discontent, over three quarters of respondents in the UNASIS July 2017 poll said that democracy was important to them personally, while less than 15 percent did not find it important (Alexseev, 2019). This level of democratic support is consistent with the results of the surveys, conducted in 2012, 2014, and 2016. More importantly, democratic support is 5-10 percent higher in these surveys, than it was in those conducted from 2002 to 2009 (Alexseev, 2019).

NDI Ukraine's 2018 nationwide survey further confirms positive trends, by suggesting that demand for a fully-functioning democracy remains high and stable (84 percent) (NDI, 2018). Moreover, there is a growing support for gender equality in political life, as more than half of Ukrainians (52 percent) support the equal participation of men and women - or more women than men - in political life (NDI, 2018). Furthermore, NDI's 2019 nationwide survey, completed in May 2019, shows a considerable increase in optimism and positive attitudes, associated with the newly elected president in particular and with the country in general (NDI Poll, 2019). Most remarkably, demand for a fully functioning democracy has increased throughout the whole country, including by ten percent both in the South and in the East. Similarly, there is a growing demand for gender equality in political life (62 percent) (NDI Poll, 2019). 
These surveys show considerable consistency in terms of Ukrainians' growing democratic support that positively correlates with declining political discontent. It follows, that even in the midst of major economic problems and considerable economic discontent, the Ukrainian public opinion firmly believes that democracy is the best path to step down.

Essentially, the high demand for EU membership that is over 55 percent (Kyovpost, 2019) can be viewed as an indicator of democratic support. More than 70\% of Ukrainians recognize the EU's fundamental values and identify with the values of human rights, individual freedoms, rule of law, peace, economic prosperity, etc. (EU Neighbors, 2019).

Moreover, both the proponents and opponents of Ukraine's European integration agree on the indispensability of the European values and find them as guiding principles for state-building (Buhbe, 2017). Not surprisingly the EU remains the most desired partner in Ukrainian public consciousness, deemed capable of transmitting a number of political values to Ukraine (Chaban and O'loughlin, 2018).

Another remarkable indicator of the democratic support is low demand for far- right anti-system political parties. This specifically applies to the activism of marginal far-right groups, including 'the Right Sector, Svoboda', the National Corpus, along with extremist groupings such as Brotherhood, OUN Volunteer Movement and others, that would spark concerns across the Ukrainian civil society and beyond. While their efforts at moving from margins to mainstream have not struck a chord with the Ukrainian population, they have strenuously strived to disseminate their illiberal ideas, and thus move their radical agenda forward (Likhachev, 2018). Motivated by the desire to "purge" the public space of everything that they find detrimental or unfavorable to a nation at war, these extremist groups would target religious, ethnic and sexual minorities, as well as liberal activists and human rights defenders (Likhachev, 2018). In effect, the conflict with Russia has allowed for their rebranding as "patriots" with some legitimizing effects on their activities. Nevertheless, despite their "radicalizing effect" on some nationalistic segments of Ukrainian society, none of the far-right parties managed to overcome the passing barrier to enter the Parliament. The electoral alliance comprised of Svoboda the Right Sector and National Corps won only 2.15 percent of the vote (Vorobiov, 2019).

While there has been negligible public support for far-rightists and they are highly unlikely to gain greater political power, the advancement of robust civil society organizations is essential for making the Ukrainian society more immune to such extremist groups and their illiberal ideas.

In terms of both attitudinal and behavioral dimensions, it is noteworthy that a major impediment to democracy consolidation is lingering post-Soviet "informality" in the form of behavioral practices, such as tolerance towards informal governance, the use of informal connections and networks in exchanges of favors, corruption, etc (Kakachia et al, 2019). The latter has long inflicting huge suffering on the country by condemning it to underdevelopment and inability to 
Overcoming the Authoritarian Legacy? Understanding Regime Change in Ukraine

implement reforms. Even though it would be an exaggeration to regard graft as a lifestyle, the deeprooted behavioral practices do not tend to fade away smoothly and swiftly. Clearly, while passing laws and implementing reforms may be straightforward, erasing historical mentalities and behavioral practices is more complex. Hence, it is impossible to neglect the residual influence of informal institutions, cultural norms, values, and ethics.

The results of the 2018 USAID/ENGAGE Anti-Corruption Poll demonstrate that while citizens regard political corruption of the highest echelons to be the most serious problem, everyday corruption that respondents themselves come across in their daily lives is perceived as a less serious problem (81.6\% of respondents named it a very serious or rather serious problem) (DIF, 2018). That said, citizens condemn high-level corruption but regard petty corruption as a "justifiable evil" (Lough and V. Dubrovskiy, 2018, p. 2). While a great many respondents see a determination to defeat corruption among ordinary people (72.7\%), mass media (47.3\%) and NGOs (41.9\%), there is a series of barriers to people's participation in anti-corruption campaigns. The reasons include the disbelief in the possibility of major breakthroughs through such actions (71.8\% of respondents), lack of sufficient guarantees protecting personal safety of participants (70.9\%) as well as low trust in the ways that government copes with corruption (DIF, 2018).

This picture is linked to the elements of political disaffection as a result of low trust in public institutions and civil society organizations, compounded by the adverse effects of authoritarian legacy. Meanwhile, breaking with the "culture of corruption" and "informality" is essential for democracy consolidation.

One of the biggest challenges is overcoming the residual influence of oligarchy, given that oligarchs tend to selectively support new laws and reform that seem conducive to maintaining and increasing their wealth and fiercely oppose to those that may somehow jeopardize their positions (Bayramov and Marusyk, 2019, pp. 80-81).

Even though there have been changes in the balance of power among the biggest oligarchs in Ukraine since the Maidan Revolution, curbing its residual influence remains an urgent priority. Studies show that during Poroshenko's presidency, the sharing out of monopolies among leading business groups continued with slow progress on de-monopolization (Lough and Dubrovskiy, 2018, p. 23). While Poroshenko was trying to balance various oligarchic interests, he continued to be one of those he tried to manage. Meanwhile, Poroshenko's perceived conflict of interest furthered fuelled public distrust of the government (European Parliament, 2017). Some observers note that what describes the Ukrainian oligarchs is their tendency to apply the "rule by law" rather than "rule of law." Meanwhile, in conditions of systemic and in particular, judicial corruption, the law becomes a purchasable commodity (Bayramov and Marusyk, 2019, p. 80). 
Not surprisingly the EU has been giving great weight to defeating oligarchy, routinely emphasizing that there could be no meaningful progress on the implementation of the Association Agreement if the oligarchy keeps exerting tremendous influence over the Ukrainian economy, politics and media (European Parliament, 2018). While Zelensky's government's reform agenda provides grounds for optimism, the process of deoligarchisation considerably depends on broader economic, political, and legal reforms, that would lead Ukraine down to the path to consolidated democracy.

Overall, while broad democratic support for post-Maidan political and economic transformation seems promising, one of the biggest challenges involves eradicating the culture of corruption and "informality." Clearly, the improvements in attitudinal and behavioral dimensions of democratic consolidation are critical to completing the process of overcoming the residual influence of oligarchy.

\section{Institutional foundations of democracy consolidation: Towards a robust civil society}

It is hard to underestimate the importance of institutional resilience of democracy, with effective, well-established political parties as essential institutions of a democratic society.

Meanwhile, Ukraine's party system does not seem stable enough to support the democratic consolidation of the country. As a matter of fact, Ukraine's post-Soviet institutional legacy, characterized by lack of legitimacy, stability, and durability, would be long unfit to serve societal interests, thus obstructing country's democratic development (Rybiy, 2013, p. 401).

Studies show that despite the advances in democratization following the Maidan revolution, the essential features of Ukraine's party system have not undergone significant changes. As a result, the institutional bases of the Ukrainian party-political landscape and parliamentary politics have not been solidified (Fedorenko et al, 2016). The factors hindering institutionalization of political parties, include their organizational weakness, characterized by uncertain ideological platforms, frequent name changes, financing, lack of accountability and poor communication with their voters. Not surprisingly, there has been low level of trust in and identification with political parties across the Ukrainian society (Rybiy, 2013, p. 402).

The lack of ideologically-driven political parties has led to a situation, where the political and ideological preferences of Ukrainians are ambiguous and most people have a hard time identifying themselves either with left or right parties (Balyuk, 2018). Moreover, an all-Ukrainian survey suggests that considerable part of respondents (nearly half of them) would be willing to vote for a newly created political party, while a third of them find party members critical to determining what party they would vote for (Balyuk, 2018). That said, when determining their political preferences, Ukrainians tend to focus more on individuals rather than on ideologies or party programs.

Essentially, low level of trust in political parties has not been uncommon in post-Soviet countries. Decades of monopolization of the electoral arena by communist parties would be followed 
Overcoming the Authoritarian Legacy? Understanding Regime Change in Ukraine

by the emergence of populist parties, thus casting a negative light on political parties across postSoviet societies.

According to the survey conducted by Razumkov Centre for Economic and Political Studies, the most trusted government and public institutions are the president of Ukraine (79\% of respondents), the Armed Forces of Ukraine (74\%), the least trusted ones are the judicial system as a whole (72\%), local courts (66\%), political parties (63\%), as well as anti-corruption agencies (Unian, 2019). This survey suggests that there is a long way ahead to shift from charismatic appeal or rule to well-established institutions that translate leader's vision into policies sustained by appropriate structures, rules, and procedures (Robinson, 1985, p. 181).

Essentially, like many other post-Soviet countries, Ukraine is faced with "party presidentialization" syndrome - remarkable indicator of an insufficient institutionalization of party politics. The inherent unsustainability and instability of the Ukrainian regime has been vividly manifested in mass mobilizations against Leonid Kuchma regime in the 2004 Orange Revolution, and similarly by the mass protests that led to the collapse of Viktor Yanukovych regime in 2014 (Sedelius, 2015, p. 124).

While, there is no denying that Ukraine is undergoing large-scale reforms during Zelensky's presidency, Inna Sovsun, a member of the Ukrainian opposition party Holos (Voice) notes that the centralization of power remains a significant problem as it is unclear who the next president will be and how he or she will use or misuse that power (Euronews, 2020).

In effect, Ukraine finds itself in an unprecedented situation, where due to its overwhelming majority in the parliament, the president's party can put forward and pass any law with no compromise. Volodymyr Zelensky capitalized on his huge popularity and through snap elections significantly consolidated his power. He is largely treated as "savior" capable of turning Ukraine's plights around and putting it on the path to prosperity and democracy. Meanwhile, the huge power in the hands of a charismatic leader is fraught with power abuses in the absence of powerful opposition. There has been a strong tendency in Zelensky's discourse to style his regime as "people's government" or "people's servant" that introduce a new form hyper-democratic interaction between state and society (Zelensky, 2019). The Ukrainian President has tended to distance himself from his predecessors and other presidents due to his resolve to bring people to power "who will serve the people" (Zelensky, 2019). Meanwhile, the success of democratic reforms in Ukraine significantly depends on its shift from a charismatic leadership to functional democratic institutions. This, in turn, depends on Zelensky's government's political will to further institutionalize state-building by subjecting it to institutional performance and strength. 
To make all these happen, it is essential for Ukrainian civil society to boost its actorness and become an agent of democracy.

Clearly, a vibrant civil society has long been thought to be a crucial instrument for political change in countries in transition and a key component of a democratic society. It is hard to underestimate the role of a civil society in democratic consolidation. Diamond (1994), emphasizes the ways, in which a civil society can contribute to democracy consolidation: 1 Civil society "restrains" and monitors the state's power that may be misused or abused. 2 Civil society mobilizes citizens and stimulates their political participation. 3 It is an arena, within which reciprocity is learned and enforced, civic norms of tolerance, trust and compromise are generated. As a result, it facilitates peaceful regulation of conflicts through the process of participation. 4 Civil society enables to articulate and represent interests outside of political parties. 5 It mitigates conflict through crosscutting or overlapping interest. 6 Civil society recruits new leaders and equips them to participate in political life. 7 It improves the quality of democracy through election-monitoring, human rightsmonitoring and public corruption-monitoring. Moreover, it disseminates alternative information, thus lowering the possibility of state censorship or state-controlled biased information, especially in respect to human right violations. 8 Civil society reinforces democratic legitimacy and governance, by making it accountable, inclusive, and responsive (Uzul, 2010, p. 50).

Therefore, all these functions of the civil society suggest that it is a powerful agent of democracy.

Studies show the Ukrainian civil society has been consistently standing up for its European choice even after the Revolution of Dignity. More specifically, civil society organizations have been actively promoting and overseeing reforms that would lead to the implementation of the Association Agreement with the European Union. The largest and most influential reform network - the Reanimation Package of Reforms (RPR) has brought together NGOs, reform groups and experts, who form, develop, and promote a reform agenda, targeting anti-corruption, judiciary and economic transformations. The core objective of the RPR is supporting implementation of reforms that lead to fundamental political and economic transformations (RPR, 2019). Remarkably, on the eve of the 2019 presidential and parliamentary elections RPR prepared a "to do list" for the president's reform agenda aimed to ensure the new government's unshakeable commitment to consistent implementation of the Association Agreement (Khomei, 2019). Such initiatives suggest that the Ukrainian civil society organizations move beyond the victory in the street and pursue victory in town halls and elections (Smagliy, 2017).

The EU reports would emphasize Ukrainian civil society's continuous positive role in in the promotion and monitoring of reforms, focusing specifically on the areas of human rights, anticorruption, healthcare, energy, decentralization, etc. (European Commission, 2019, p. 4). 
Overcoming the Authoritarian Legacy? Understanding Regime Change in Ukraine

While the boosting actorness of civil society organizations creates an optimistic outlook on their potential contribution to democratic consolidation, further development of their institutional capacities and networks to influence policy making and reform implementation is essential.

Studies show that the path to a vibrant and consolidated civil society has two main dimensions. The first dimension comes down to the changes in the very nature of civil society relations with the state and society and its potential and ability to foster reform, or what is often referred to as "change on the outside" (Shapovalova and Burlyuk, 2018). This has a lot to do with increasing their impact on public policy, through intensifying their interaction with public institutions and actors and most importantly, through engaging more with their constituencies. It has not been uncommon for postSoviet societies to perceive civic associations as threat to the state's power and stability, along with the belief that the state bears the ultimate responsibility for the wellbeing of the society (Terzyan, 2020).

A survey shows that most respondents welcome the state's active involvement in issues like social guarantees and display inclinations toward paternalism, while neglecting the responsibility of society members for addressing such problems. Interestingly, despite their distrust of state institutions, Ukrainians still prefer to delegate the function of wealth distribution to the state (Balyuk, 2018, p. 24).

Similarly, surveys show that there is a somewhat paternalistic attitude towards European values, in Central and especially Southern and Eastern Ukraine. The respondents would often claim that it is the government's duty to ensure human rights and everyone's equality before the law, as well as to create opportunities for self-realization, etc. Overall, respondents in Eastern Ukraine are more inclined to believe that values shared by EU-Europeans and most Ukrainians should be implemented from the outside and installed by the state (Buhbe, 2017). By contrast, respondents in Western Ukraine have a better understanding of the values shared by the EU-Europeans well acknowledging the duties of ordinary citizens (Buhbe, 2017). Clearly, greater engagement and effective communication with various social groups is pivotal to squashing public misperceptions of CSOs and their activities. Thus, the "change on the outside" is critical to reducing the apathy of the wider public and stimulating their political participation.

The second crucial dimension is "change on the inside," pertaining to the nature of civil society per se i.e. with the way it is organized and operates. This in turn, has much to do with institutional and professional development of CSOs that would equip them to influence policy making. At the organizational level institutional development includes enhancing organizational capacities for governance, improving decision-making and conflict management skills, as well as clarifying organizational mission, identity. and values. This is particularly important as a great many CSOs in 
Ukraine were established in response to certain narrow needs or funding priorities without a welldefined mission, strategic plans, and a strategy of impact (Terzyan, 2020). That said, they would largely fail to represent interests and address the specific needs of their constituencies.

In conclusion, a well-informed observer aptly notes that "strong, autonomous societal organizations and networks may not always be democracy's allies, but their absence is almost always democracy's enemy" (Evans, 2011, p. 46). Therefore, it is hard to underestimate the importance of robust CSOs in terms of Ukraine's democratic consolidation.

\section{Conclusion}

The analyses of the Maidan range from its treatment as a manifestation of the intensifying geopolitical confrontation between the West and Russia, to its reductionism to economic discontent, fueled by the mobilizational power of the social media. Yet, there seems to be a broad consensus on Maidan being a testament to the crisis of the post-Soviet political model resting on repressive rule, as well as a manifestation of the growing antagonism between the European and Russian visions of the shared neighborhood.

The post-Maidan state-building has been focusing on overcoming the legacy of corruption, residual influence of oligarchy and broader rule of law reforms that are critical to democracy consolidation.

In terms of the attitudinal dimension of democratic consolidation, there has been broad public support for democratic state-building across the Ukrainian society since the Maidan Revolution. One of the remarkable indicators of democratic support is low demand for far- right radical political parties, as well as high demand for EU membership. The EU has been largely viewed as a "role model" identified with the values of human rights, rule of law, peace, economic prosperity, individual freedoms, etc.

In terms of behavioral dimension, a major impediment to democracy consolidation is lingering post-Soviet "informality" in the form of behavioral practices, such as tolerance towards informal governance, the use of informal connections and networks in exchanges of favors, corruption, etc. The latter has long condemned the country to underdevelopment and inability to implement reforms. Even though it would be an exaggeration to regard graft as a lifestyle, it takes a long time for deep rooted behavioral practices to fade away. While passing laws and implementing reforms may be straightforward, erasing historical mentalities and behavioral practices is more complex. Thus, fighting against the "culture of corruption" is an integral part of anti-corruption policies. Arguably, the improvements in attitudinal and behavioral dimensions of democratic consolidation are critical to completing the process of overcoming the residual influence of oligarchy. 
Overcoming the Authoritarian Legacy? Understanding Regime Change in Ukraine

In terms of institutional foundations of democratic consolidation, one of the biggest challenges involves increasing institutional capacities of political parties and civil society organizations. The factors hindering institutionalization of political parties, include their organizational weakness, characterized by uncertain ideological platforms, lack of accountability and poor communication with their voters. As a result, there has been low level of trust in and identification with political parties across the Ukrainian society. This has led to "party presidentialization" - a situation where the voters tend to pay more attention to leaders, rather than to principles of political parties. While Zelensky remains immensely popular, the logic of democratic consolidation requires to shift from charismatic appeal or rule to well-established institutions that translate leader's vision into policies sustained by appropriate structures, rules, and procedures. As for civil society organizations, along with their institutional development, it is essential for them to engage more with their constituencies, thus contributing to their democratic socialization. It has not been uncommon for post-Soviet societies to perceive civic associations as threat to the state's power and stability, along with the belief that the state bears the ultimate responsibility for the wellbeing of the society. Not surprisingly, studies show inclinations toward paternalism across the Ukrainian society, coupled with misconceptions about civil society organizations. Therefore, CSOs have a critical mission of breaking down lingering misperceptions and transforming citizens from spectators into actors.

Future research is essential to account for further dynamics of regime change and democracy consolidation in Ukraine. 


\section{References}

Alexseev, M., (2019). Ukraine's Counterintuitive Democratic Stoicism: Supporting Democracy-Building in a War-Torn State. PONARS Eurasia Policy Memos (retrieved from http://www.ponarseurasia.org/memo/ukraines-counterintuitive-democratic-stoicism-supportingdemocracy-building-war-torn-state) .

Ambrosio, T. (2007). Insulating Russia from a colour revolution: How the Kremlin resists regional democratic trends. Democratisation, 14(2), 232-252.

Balyuk, S., Klauning, N., Koval, M., Röthig, M. and L. Chetvertukhin (2018). The Attitude of Ukrainians Toward Social Democracy Public opinion poll results (retrieved from 2020. http://library.fes.de/pdf-files/bueros/ukraine/14762.pdf ).

Bayramov, A. and Marusyk, Y. (2019), Ukraine's unfinished natural gas and electricity reforms: one step forward, two steps back. Eurasian Geography and Economics, 60(1), pp. 1-24.

Black, J. L .and Johns, M. (Eds.). (2016). The return of the cold war: Ukraine, the west and Russia. Routledge.

Bohdanova, T. (2014). Unexpected revolution: the role of social media in Ukraine's Euromaidan uprising. European View, 13(1), 133-142.

Buhbe, M., "How Ukrainians perceive European values: Main results of an empirical survey," (2017), Accessed on April 17, 2020. https://library.fes.de/pdf-files/id-moe/13731.pdf .

Chaban, N. and O'loughlin, B. (2018). The EU's crisis diplomacy in Ukraine: The matrix of possibilities (retrieved from https://jia.sipa.columbia.edu/eus-crisis-diplomacy-ukraine-matrixpossibilities ).

Delcour, L. and Wolczuk, K. (2015). Spoiler or facilitator of democratization?: Russia's role in Georgia and Ukraine. Democratization, 22(3), 459-478.

Delcour, L. and Wolczuk, K. (2017). Between the Eastern partnership and the Eurasian economic union: Competing region-building projects in the 'common neighbourhood'. Theorizing the European neighbourhood policy, 187-206.

DIF (2018). Corruption in Ukraine: Perception, Experience, Attitudes (retrieved from https://dif.org.ua/en/article/one-out-of-three-ukrainians-ready-to-join-organized-counteraction-tocorruption ).

Diuk, N. (2014), The Maidan and Beyond: Finding Ukraine. Journal of Democracy, 25(3), pp. 83-89.

EU Neighbors (2019). EU Neighbors opinion survey 2019: Ukraine (retrieved from https://www.euneighbours.eu/en/east/stay-informed/publications/opinion-survey-2019-ukraine ).

Euronews (2020), Could Volodymyr Zelensky's proposed reforms lead to centralized power in Ukraine? 27 February (retrieved from https://www.euronews.com/2020/02/27/could-volodymyrzelensky-s-proposed-reforms-lead-to-centralised-power-in-ukraine).

European Commission (2019). Association Implementation Report on Ukraine, https://eeas.europa.eu/sites/eeas/files/swd_2019_433_f1_joint_staff_working_paper_en_v4_p1_105 6243.pdf

European Parliament (2017). The state of implementation of the associations and free trade agreements with Ukraine, Georgia and Moldova with a particular focus on Ukraine and systemic analysis of key sectors from http://www.europarl.europa.eu/RegData/etudes/STUD/2017/603836/EXPO_STU(2017)603836_EN .pdf ).

European Parliament (2018). Report on the implementation of the EU Association Agreement with Ukraine (2017/2283(INI)) (retrieved from https://www.europarl.europa.eu/doceo/document/A8-2018-0369_EN.html ).

Evans, A. B. (2011). The failure of democratization in Russia: A comparative perspective. Journal of Eurasian Studies, 2(1), 40-51.

Fedorenko, K., Rybiy, O. and Umland, A. (2016). The Ukrainian party system before and after the 2013-2014 Euromaidan. Europe-Asia Studies, 68(4), 609-630. 
Overcoming the Authoritarian Legacy? Understanding Regime Change in Ukraine

Fedunyak, S. (2015). The Ukrainian Revolution in International Context. Ukraine After the Euromaidan: Challenges and Hopes, pp. 97-104.

Gerasimov, I. (2014). Ukraine 2014: The First Postcolonial Revolution. Introduction to the Forum. Ab Imperio, 2014(3), 22-44.

Gunther, R. and J. R. Montero (2006). The multidimensionality of political support for new democracies: conceptual redefinition and empirical refinement. Political Disaffection in Contemporary Democracies. London: Routledge

Ibtimes (2018). Ukraine economy to fall? Gross domestic product to shrink by $12 \%$, says World Bank (retrieved from https://www.ibtimes.com/ukraine-economy-fall-gross-domestic-productshrink-12-says-world-bank-2126818).

Kakachia, K., Lebanidze, B. and V. Dubovyk. "Defying marginality: explaining Ukraine's and Georgia's drive towards Europe." Journal of Contemporary European Studies 27.4 (2019), 451-462.

Khomei, O., (2019). Increasing the power of civil society in Ukraine" (retrieved from https://neweasterneurope.eu/2019/12/22/increasing-the-power-of-civil-society-in-ukraine/ ).

Krilova, A. (2015). The West Against Russia: Geopolitical and Military Aspects. The Paths to Peace and Security, pp. 86-96 \{И. А. Крылова, "Запад против России: геополитические и военные аспекты." Пути к миру и безопасности 2 (2015): 89-96\};

Kuzio, T. (2017). Ukraine between a constrained EU and assertive Russia. JCMS: Journal of Common Market Studies, 55(1), 103-120.

Kyivpost (2019) “Almost 60 percent of Ukrainians ready to vote for Ukraine's accession to EU at referendum," January 1, 2019, Accessed on April 28, 2020.

https://www.kyivpost.com/ukraine-politics/almost-60-percent-of-ukrainians-ready-to-vote-forukraines-accession-to-eu-at-referendum.html.

Likhachev, V., (2018). Far-right extremism as a threat to Ukrainian democracy." Nations in Transit Brief, (retrieved from https://freedomhouse.org/report/analytical-brief/2018/far-rightextremism-threat-ukrainian-democracy ).

Linz, J.J. and A. Stepan. Problems of democratic transition and consolidation: Southern Europe, South America, and post-communist Europe. JHU Press, 1996

Lough, J. and Dubrovskiy, V. (2018), Are Ukraine's anti-corruption reforms working? Research Paper. Russia and Eurasia Programme, (retrieved from https://www.chathamhouse.org/sites /default/files/publications/research/2018-11-19-ukraine-anticorruption-reforms-lough-dubrovskiy.pdf).

Markov, S. (2017) Hybrid War Against Russia. Litres, \{Сергей Марков, «Гибридная война» против России. Litres, 2017\}.

NDI (2018). National Democratic Institute, “Opportunities and challenges facing Ukraine's democratic transition (retrieved from https://www.ndi.org/publications/opportunities-andchallenges-facing-ukraine-s-democratic-transition ).

NDI Poll (2019). Opportunities and challenges facing Ukraine's democratic transition (retrieved from https://www.ndi.org/publications/ndi-poll-opportunities-and-challenges-facingukraine-s-democratic-transition ).

Neumann, I. B. (2016). Russia and the idea of Europe: a study in identity and international relations. Taylor \& Francis.

Piechota, G and Rajczyk, R. (2015). The role of social media during protests on Maidan. Communication Today, no. 2, pp. 86-96.

Reanimation Package of Reforms (2019) (retrieved from https://rpr.org.ua/en/about-us/ ).

Roberts, S. and Ziemer, U. (2018). Explaining the pattern of Russian authoritarian diffusion in Armenia. East European Politics, 34(2), 152-172.

Robinson, J. C. (1985). Institutionalizing charisma: Leadership, faith \& rationality in three societies. Polity, 18(2), 181-203. 

423.

Rybiy, O. (2013). Party system institutionalization in Ukraine. Demokratizatsiya, 21(3), 401-

Samokhvalov, V. (2015). Ukraine between Russia and the European Union: triangle revisited. Europe-Asia Studies, 67(9), 1371-1393.

Schedler, A. (1998). What is democratic consolidation?. Journal of democracy, 9(2), 91-107.

Sedelius, T. (2015). Party presidentialization in Ukraine. In The Presidentialization of Political Parties (pp. 124-141). Palgrave Macmillan, London.

Shapovalova, N. and O. Burlyuk (2018). Civil Society and Change in Ukraine PostEuromaidan: An Introduction. In Civil Society in Post-Euromaidan Ukraine: from Revolution to Consolidation, 193, pp.11-38.

Shevtsova, L. (2014). The Maidan and Beyond: The Russia Factor. Journal of Democracy, 25(3), 74-82.

Shveda, Y. (2015). The Revolution of Dignity in the Context of Theory of Social Revolutions. Ukraine After the Euromaidan, pp. 83-94.

Shveda, Y.and Park, J. H. (2016). Ukraine's revolution of dignity: The dynamics of Euromaidan. Journal of Eurasian Studies, 7(1), 85-91.

Smagliy, K. (2017), A wake up call for Ukraine's civil society. Kennan Cable, (25) (retrieved from https://www.wilsoncenter.org/publication/kennan-cable-no25-wake-call-for-ukraines-civilsociety).

Stepanenko, V. (2015). Ukraine's Revolution as De-Institutionalization of the Post-Soviet Order. Ukraine After the Euromaidan: Challenges and Hopes, pp. 29-46.

Surzhko-Harned, L. and Zahuranec, A. J. (2017). Framing the revolution: the role of social media in Ukraine's Euromaidan movement. Nationalities Papers, 45(5), 758-779.

Terzyan, A., Towards a vibrant civil society in Ukraine and Armenia. Emerging Europe on April (retrieved from https://emerging-europe.com/voices/towards-a-vibrant-civil-society-inukraine-and-armenia/) .

Unian (2019). Almost $80 \%$ of Ukrainians trust in Zelensky - poll, UNIAN (retrieved from https://www.unian.info/politics/10688256-almost-80-of-ukrainians-trust-in-zelensky-poll.html ).

Usul, A.I. (2010). Democracy in Turkey: the impact of EU political conditionality. Routledge

Viktor Stefánsson, Is Russia Europe's Other? How the Ukraine Crisis Reinforces European Identity Formation (Doctoral dissertation), (2015) (retrieved from https://skemman.is/bitstream/1946/22766/3/Is\%20Russia\%20Europe\%27s\%20Other\%20SkemmanPDF.pdf ).

Vorobiov (2019). Ukrainian Voters Upend their Parliament, (retrieved from https://jamestown.org/program/ukrainian-voters-upend-their-parliament/).

Way, L. (2014). The maidan and beyond: civil society and democratization. Journal of Democracy, 25(3), 35-43.

Zelensky (2019). Volodymyr Zelenskyy's inaugural address (retrieved from https://www.president.gov.ua/en/news/inavguracijna-promova-prezidenta-ukrayini-volodimirazelensk-55489).

Zhuk, S. I. (2014). Ukrainian Maidan as the Last Anti-Soviet Revolution, or the Methodological Dangers of Soviet Nostalgia (Notes of an American Ukrainian Historian from Inside the Field of Russian Studies in the United States). Ab Imperio, 2014(3), 195-208. 